\title{
PRIORITY NEEDS REFERRED BY FAMILIES OF RARE DISEASE PATIENTS
}

\author{
Geisa dos Santos Luz', Mara Regina Santos da Silva², Francine DeMontigny ${ }^{3}$
}

\begin{abstract}
${ }^{1}$ Ph.D. in Nursing. Consultor Associação dos Familiares, Amigos e Pessoas com Doenças Graves. Rio Grande do Sul, Brazil. E-mail: geisaluz@yahoo.com.br

2 Ph.D. in Nursing. Professor, Post Graduation in Nursing Program, Universidade Federal do Rio Grande, Rio Grande, Rio Grande do Sul, Brazil. E-mail: marare@brturbo.com.br

${ }^{3}$ Ph.D. in Nursing. Professor, Post Graduation in Nursing Program, Université du Québec. Outaouais, Gatineau, Québec, Canada. E-mail: francine.demontigny@uqo.ca
\end{abstract}

\begin{abstract}
Rare diseases cause strong impact in families and generate needs beyond those associated with the most frequent diseases. Some of these needs are the inclusion of new responsibilities and the relationship with the healthcare and social services. This study is aimed at identifying the priority needs of families of rare disease patients as perceived from the time of diagnosis. This is a qualitative study conducted with 16 relatives of rare disease patients who live in the state of Rio Grande do Sul. Data were collected from November 2012 to March 2013, through semi-structured interviews and submitted to content analysis, based on the bioecological system of human development. The results indicated the following priority needs: access to social and healthcare services; knowledge about rare diseases; social support structures; acceptance and social integration; preservation of personal and family life. It was concluded that (re)organizing services and meeting the specific needs are preconditions to qualify nursing care and soften the impact the rare disease has on the family. DESCRIPTORS: Rare diseases. Family. Nursing.
\end{abstract}

\section{NECESSIDADES PRIORITÁRIAS REFERIDAS PELAS FAMÍLIAS DE PESSOAS COM DOENÇAS RARAS}

\begin{abstract}
RESUMO: As doenças raras provocam forte impacto nas famílias, gerando necessidades que ultrapassam aquelas associadas às doenças mais frequentes. A incorporação de novas responsabilidades e a relação com serviços sociais e de saúde são algumas dessas. Este estudo objetiva identificar as necessidades prioritárias das famílias de pessoas com doenças raras, percebidas a partir do diagnóstico. Trata-se de um estudo qualitativo desenvolvido com 16 familiares de pessoas com doenças raras, residentes no Rio Grande do Sul, cujos dados foram coletados entre novembro/2012 e março/2013, por meio de entrevista semiestruturada e submetidos à análise de conteúdo, balizada pela teoria bioecológica do desenvolvimento humano. Os resultados apontam como prioritárias as necessidades de: acesso aos serviços sociais e de saúde; conhecimento sobre doença rara; estruturas de apoio social; aceitação e inserção social; preservação da vida pessoal e familiar. Conclui-se que (re)organizar os serviços e conhecer as especificidades das necessidades são pré-condições para qualificar a assistência de enfermagem e amenizar o impacto que a doença rara provoca na família.
\end{abstract}

DESCRITORES: Doenças raras. Família. Enfermagem.

\section{NECESIDADES PRIORITARIAS DE LAS FAMILIAS DE PERSONAS CON ENFERMEDADES RARAS}

RESUMEN: Las enfermedades raras provocan fuerte impacto en las familias, generando necesidades más allá de los relacionados con las enfermedades más frecuentes. La incorporación de nuevas responsabilidades y la relación con los servicios sociales y de salud, son algunas de ellas. Este estudio tiene como objetivo identificar las necesidades prioritarias de las familias de las personas con enfermedades raras, percibidas desde el diagnóstico. Se trata de un estudio cualitativo realizado con 16 miembros de la familia de las personas con enfermedades raras, los residentes de Rio Grande do Sul, cuyos datos fueron recolectados entre noviembre/2012 y marzo/2013, a través de entrevistas semiestructuradas y sometido a análisis de contenido, impulsado por La teoría bio-ecológica del desarrollo humano. Los resultados indican como prioridad las necesidades de: acceso a los servicios sociales y de salud; conocimiento sobre las enfermedades raras; estructuras de apoyo social; la aceptación y la integración social; preservación de la vida personal y familiar. Llegamos a la conclusión de que (re)organizar los servicios y satisfacer las necesidades específicas son condiciones previas para calificar la atención de enfermería y amortiguar el impacto de las causas de enfermedades raras en la família.

DESCRIPTORES: Enfermedades raras. Familia. Enfermería. 


\section{INTRODUCTION}

Rare diseases affect up to $65 / 100,000$ people or 1.3 people for every 2,000 individuals. ${ }^{1}$ Most diseases $(80 \%)$ have genetic origin, and involve one or more genes or chromosomal anomalies and around $75 \%$ manifest in childhood. Other rare diseases are caused by bacterial or viral infections, allergies or degenerative, proliferative or toxic (chemicals, radiation) processes. ${ }^{2}$ Mucopolysaccharidosis type II (MPS), sickle cell anemia, cystic fibrosis and phenylketonuria are among the rare genetic diseases. In general, these diseases can cause physical, mental, behavioral and sensory abnormalities, compromising several organic systems and making patients and their families dependent on specialized services and multi-professional monitoring for treatment.

Having a rare disease patient in the family has important implications on the family as a whole, particularly on their relationship with the community in which they dwell and the healthcare institutions, which are not always ready to care for them. The families are faced with lack of information on the disease, difficult access to diagnosis and treatment and lack of qualified healthcare professional teams. ${ }^{3}$ Moreover, the family suffers at work, since usually one of the parents stops working to care exclusively for the child. As a result, the families' financial status is affected at the same time in which the family is faced with high treatment costs. ${ }^{3}$

In this sense, having a rare disease patient in the family generates countless needs. In general, these needs are related to expectations and desires and are perceived and expressed as demands on the healthcare services. Although they result from having a rare disease patient in the family, these needs are similar among families who experience similar situations. ${ }^{4}$ Usually manifested as problems, sufferings, or solutions, they interfere in family life: a symbolic or material fact that can either indicate a need or a fault. The family's needs can also point toward a solution for the situation they are going through.

Health-related needs represent what individuals and groups require to have satisfactory social conditions to generate health. They are related to the human essence/existence and to the relational, communicational, emotional, financial and cognitive/ spiritual dimensions. ${ }^{5-6}$ Within the family context, rare diseases add different needs to those usually experienced in common diseases.

This study approaches the needs of families with rare disease patients and uses the bioecological model of human development as reference ${ }^{7}$ to enable an examination of family interactions with the different contexts in which their members transit. The model is structured into four interrelated systems: process (interactions), context, person and time. Process is the central system ${ }^{7}$ and the origin of the different types of needs in families of rare disease patients.

Process refers to the different forms of "faceto-face" interaction the person/family experiences with their context. These interactions incorporate the growing level of complexity experienced by humans. For example, the way in which families interact with the healthcare services develops from the face-to-face experience they have of the several processes within the different contexts. The most significant processes involve member interactions and include their personal, cultural and social characteristics and other contexts such as work, school and friends.

In family life, these interactions involve the parents' expectation toward the birth of a healthy child, the family composition (dyad, triad) and the stage of the family life cycle (marriage, children's birth, children's adolescence and elderly parents), factors that add more or less experience to administer the problems jointly. They also involve the family's economic status, which can favor their traveling to reference centers, buying medication and accessing private services. As a rule, social interactions can change from the time of disease onset: concerns in relation to disease treatment prevent the family's natural environment from remaining the same as before.

The family's needs are generated within their own microsystem, mesosystem or macrosystem. Knowing them provides consistent content to care for families of rare disease patients. Using the bioecological model as the basis to learn the needs the families have from the time a rare disease is diagnosed is important to build nursing knowledge for rare diseases. Therefore, this study is aimed at identifying the priority needs of families with rare disease patients as perceived from the time of diagnosis.

\section{METHOD}

An exploratory qualitative study developed with the participation of 16 families represented by the parents or close relatives of rare disease patients, recruited from three rare disease reference services in the state of Rio Grande do Sul (RS): Serviço de Referência em Triagem Neonatal (SRTN, Neonatal 
Screening Reference Service), Associação Gaúcha de Assistência à Mucovisicidose (AGAM, Cystic Fibrosis Care Association of Rio Grande do Sul) and Associação Gaúcha de Mucopolissacaridose (AGMPS, Mucopolysaccharidosis Care Association of Rio Grande do Sul). The SRTN is based in the Hospital Materno-Infantil Presidente Vargas (HMIPV), in Porto Alegre-RS, a reference center for the heel prick, phenylketonuria, hypothyroidism, sickle cell anemia and cystic fibrosis sample tests. The AGAM cares for approximately 237 patients and is based in the Hospital de Clinicas de Porto Alegre. At the time of study data collection, 45 patients were registered with the AGMPS. This Association has the objective of disseminating information on the MPSs, promoting events and offering support for patients and their families to have access to treatment.

The families were selected in conjunction with the reference services and association coordinators, according to the following criteria: a) mother, father and/or relative of the rare disease patient; b) resident in Rio Grande do Sul; c) registered with the Rio Grande do Sul reference services. The families were enrolled in the study only after the participants had expressly agreed to and signed the Informed Consent Form.

Families who live in other areas of the State and those who live in the capital were uniformly distributed during family recruitment. The state capital is where the reference healthcare centers for rare disease patients are concentrated, and families from other regions go there for care. This distribution permitted a detailed visualization of the families' needs in relation to diagnosis, treatment and challenges, such as traveling.

The data were collected using semi-structured interviews recorded with the participants' consent, from November 2012 to March 2013. Based on Urie Bronfenbrenner's bioecological model of human development, a theoretical structure was created for data organization, interpretation and analysis that includes the four elements of the bioecological model: process, context, person and time. ${ }^{7}$ Content analysis ${ }^{8}$ was as follows: interview reading and rereading, information coding, and thematic nuclei delimitation using regularities and patterns identified in words, phrases and behaviors shown during the interviews as reference. The process of analysis identified the following needs: access to the social and healthcare services; knowledge about the disease; support structure; acceptance and integration into the community; preservation of family and personal life.
The study received certification from the Research Ethics Committee of the institution to which it is linked (Opinion no. 135.831/2012). The guidelines of Resolution 466/2012 were complied with, and participants' anonymity was guaranteed.

To preserve anonymity, the families were identified by a code formed by the letter F (family), followed by a sequence number representing the order in which the interviews were conducted (F1 to F16).

\section{RESULTS}

\section{Family characterization}

The age of the 16 family members who participated in this study ranged from 24 to 63 years: 14 were mothers, one a grandmother and one a father of a rare disease patient. Three lived in the state capital, five in the metropolitan region and eight in other regions. The rare diseases diagnosed were mucopolyssacharidosis, cystic fibrosis and phenylketonuria.

The three families living in the state capital were represented by three mothers (F1, F2 and F3), aged between 38 and 52 years. Two are married and one, separated. All had completed secondary education; one works full-time in commerce and two are homemakers. One of the latter was a volunteer in a rare disease patients' association. The families are nuclear and formed by the couple and the child and by both parents and two children. The family income is BRL 678.00, BRL 2,500.00 and BRL $5,000.00$, respectively, for the three families. The mothers' religions were Evangelical, Spiritist and Catholic. The children with rare diseases were aged 21, 16 and 10 years, and were diagnosed with cystic fibrosis (F1 and F2) at ages 5 years and 6 months, and with mucopolyssacharidosis (F3) at age 7 years.

The families who live in the metropolitan region were represented by four mothers, aged between 28 and 63 years old, and by a 62 -year-old grandmother. Two are divorced, two are married and one is single. The families were formed by two to four members, with one to three children. In one of the families (F5), two children had the rare disease. Two mothers and the grandmother are Catholic, one follows Umbanda and one follows no religion. Two mothers work full-time, two do not work and the grandmother is a volunteer in a rare disease patients' association. The average income for these families ranged from BRL 999.00 to BRL 2,500.00 Regarding education, one mother 
completed primary education, two did not complete secondary education, and two completed secondary education. The children with rare diseases were aged between 10 and 32 years and were diagnosed in the first week of life, and at seven years old with mucopolyssacharidosis (1), phenylketonuria (3) and cystic fibrosis (1).

The eight families who live in farther regions (up to $520 \mathrm{~km}$ from the capital) were represented by seven mothers and one father aged between 29 and 50 years old. Five are married, two have stable relationships and one is separated. The families are formed by three to four members, with one and two children. Five participants worked full-time, the father is autonomous and two are unemployed. The average monthly income ranged from BRL 1,000.00 and BRL 2,999.00 One participant completed primary education, one has not completed secondary education and five mothers and the father have completed secondary education. Four participants were Catholic, one, Evangelical, one, Spiritist, one Lutheran and one did not follow any religion. The children were aged between 3 and 16 years and had been diagnosed with mucopolyssacharidosis (1), phenylketonuria (5) and cystic fibrosis (2) between the first week and the first year of life.

\section{Priority needs mentioned by families of rare disease patients}

\section{Access to social and healthcare services}

All the families mentioned the need to access social and healthcare services as a priority. Access has a different configuration according to the disease stage in which the patient is. Initially, when the diagnosis is not yet defined but the first symptoms have already been manifested, healthcare services do not seem to solve the patient's problems. Over time, this stage progresses to the need for specialized services in large centers. After confirmation of diagnosis, the families experience traveling problems, with frequent trips to the neonatal or genetic screening reference services and political and social problems (insufficient public social and healthcare policy and financial difficulties to continue traveling and treatment). At the stage of main treatment maintenance, the families are faced with the need to obtain juridical support to guarantee treatment. Regarding rehabilitation services, the difficulty of continuous access to other services, including physical therapy, speech therapy, occupational therapy, among others, is prevalent.
For families living in other areas of the state, access was associated to the availability of transport (own or public) and time (parents released from work on the date of consultation) and to the family's economic status. We usually need two days to go. We go in the early hours and spend the entire day there [in the capital] and then return. So, he [the husband] misses two days of work [...] (F15). We spend [money] with the doctor, transportation and many things (F11).

For families whose child was diagnosed in the first year of life, through the manifestation of disease symptoms or abnormal heel prick tests, access to healthcare services started soon after birth and investigation has permitted early diagnosis and treatment, without sequelae. We were followedup at the hospital, by a pediatrician who worked at the outpatient clinic and then continued follow-up at the healthcare center. [We went to] the healthcare center due to severe malnutrition (F16). She did the heel prick test and then after some days they sent me a paper where they scheduled to consultation with a doctor [...] (F11).

In some situations, access to healthcare and social services was obtained through juridical support. The families had to appeal to legal processes in order for their child to receive the high cost treatment, which is often not included in the public healthcare system list. Families of children with phenylketonuria faced several difficulties to obtain the special diet: [...] the process has been going on for three years and there are no results. I started the lawsuit with the Public Ministry - there has been no result and I still do not receive any help from the government (F15).

The families mentioned the following for cystic fibrosis: [...] nowadays, you have a process for all the drugs that are provided by the SUS [Sistema Único de Saúde-Unified Health System] or with the patient's CPF [Cadastro da Pessoa Física-Individual Taxpayer ID] (F6). Families of children with mucopolyssacharidosis who can receive enzymatic replacement require judicial authorization to start the treatment.

\section{Need for knowledge about the rare disease}

The family's need to know about the rare disease is linked to questions related to heredity, treatment, care required, rights of the rare disease patient and information on new research published. Parents frequently feel frustrated when faced with the lack of knowledge among healthcare professionals and society in general. The terminology adopted to denominate a large part of rare diseases if the first obstacle. A mother reported that the difficulty starts in the way the disease name is pronounced: 
[...] I went to the consultation and the doctor told me she had phenylketonuria. It was very difficult to pronounce it because this disease was totally unknown to me [...] (F11).

Regarding phenylketonuria, the lack of knowledge involves the development of cooking abilities to prepare the special diet. A father mentioned the need to obtain new recipes for his son, as follows: I think there should be a website or something like this for the families to interact, exchange recipes and give testimonials. This would be very interesting. I did search the Internet, and found many recipes, but more than half of them are wrong [...] (F8).

Another stage starts for the family when the child's/ patient's social life is broadened. Childhood is marked by the challenge of acceptance, adaptation and inclusion at school. The treatment of cystic fibrosis required that a mother, F16, exposed her daughter's health status at school and provided information regarding care to the teacher, the director and other mothers. It was by sharing information on the disease that this was shown that being different is normal, as she explained: so, for her it is quite normal, and the whole school, with approximately 50 children, knows that she takes the pill because the name of her medication is pill. [...] All the teachers know and even some students' mothers [...]. Therefore, they all know that she has to undergo physical therapy. It is a normal thing; she is different but she is normal (F16).

A mother explained that when the children become adolescents/adults, especially in cases of diseases that cause significant physical anomaly, the greatest problem is lack of knowledge and the explicit prejudice in her child's relationships with his friends from school, college, work and society, as reported in her speech: what I can tell you today is that the worst for him - which hurts me a lot - is prejudice. Prejudice is very difficult. This is the worst of all. It is very sad. It hurts him a lot, especially the nicknames he receives [...] (F10).

To meet the individual and social needs, parents feel driven to research on their child's disease. The source of knowledge was books/leaflets, congresses, the Internet and common sense/laypeople. In their long interaction with their child's rare disease, some families have learned to search for information in several sources, which provide tranquility and control of the condition within the family: [...] I started researching to learn more in books, in the library. Then I came here and took some things that the doctor gave me [...] (F10). Moreover, families can feel insecure about the future of their child's health due to the incapacity the disease can bring: to read all that can happen to my child; the doctor speaks slowly and does not omit anything [...] (F11).
The testimony of six families (F3, F11, F12, F14, F15 and F16) indicated the Internet was the main source of research on rare diseases. However, they highlighted the lack of credibility and sensationalism in some websites, as described below: [...] I was awake the whole night researching the Internet. It was terrible in the first days, because the more read the more I panicked (F3). The need for knowledge was also supplied by exchanging information with other parents. This symbolized a means of reducing the suffering of diagnosis and creating strength to move forward to the next stages of family life.

\section{Need for support structures}

The support structures needed by participants include family and social structure. The priority for family structure is having financial support and sharing the daily care for the child, including preparing the special diets. Financial support from the family was significant for these families, as it permitted buying the high cost medications that are not financed by the State.

Regarding social structure, parents expected spiritual help and support from friends in difficult times. A mother, F3, whose daughter has MPS, mentioned that she sought alternatives to overcome the difficulties and provide the required treatment. The social sensitization she undertook led to a wide reaching collective action in the municipality she lives. She explained it as follows: [...] a party was held to help me with her treatment [...]. One day before the event 1,800 tickets had been sold (F3).

In addition to economic support, help from friends and close relatives in caring for the child was mentioned as being important to maintain the family unit. Testimonials from six family members (F1, F2, F3, F11, F14 and F15) clarified that the couple could have some moments of social life or attend commitments that took them away from the family only due to support from friends and relatives. The latter were available to care for the child and generated tranquility and confidence in the family system: [...] if I had to go out, I would leave [my son] with a friend who looked after him (F2). My mother looks after him for us or one of my sisters stays with him at home so that we can go out (F11).

Another type of support mentioned by the families is linked to region. This is the source of faith and hope to face daily living with the rare disease. This statement is reflected in F1's speech, who mentions the influence of the religious group in facing the adversities in family life: when we moved over 
here, we started going to the Baptist Church and were welcomed. So, we profess this faith and believe unconditionally that we are competent to do our part [...] (F1).

\section{Need to be accepted and integrated into the community}

The families mentioned the need to interact with people facing the same rare disease problems and with other people from the community as well. Interacting with people from families with rare disease patients no doubt favors sharing experiences and obtaining responses to their needs. However, interacting with other people outside the context of the disease is also valuable as it reduces the social stigma that labels them as fragile. Rare disease patients and their families become citizens with similarities and problems who are able to administer their own lives once they are inserted into community life routine.

Integrating a child in the school environment was a difficult experience. However, it also facilitated social integration for the rare disease patient. A mother, F3, mentioned it was difficult to find inclusive schools and that even when she found one, the actions did not always correspond to the school inclusion rules. This is what she said: [...] when my mother went to school to fetch her, she was locked in a room alone with the teacher. They did not make any effort for her to improve or calm down [...]. And yet the school said they worked on inclusion [...] (F3).

Also, the F9 mother described her experience in integrating her daughter at school as positive, especially with regard to the special phenylketonuria diet. The family was surprised by the teacher's attitude. She organized a weekly "fruit day" to emphasize its importance for the child's treatment. The other children were led to reflect on solidarity and inclusion, as she described: in general, the school snack is junk food. They organized it so that Wednesday was the fruit day to help the friend who could not eat that stuff [...]. The teacher organized it. And I have kept in touch with her since then (F9).

\section{Need to preserve personal and family life}

The family members need to preserve their personal and family life and not live exclusively for the disease. The rare disease patient's physical and emotional progression demands intensive and specific care. In spite of this, the competence to care for the child has been shown to be essential for the parents' feelings of self-esteem, self-sufficiency and confidence. The child's healthy development in the social, school/university, profession and emotional life has reaffirmed the parents' confidence of having cared well for their child, especially in families with young/adult children. The parents' work was an activity that brought financial support and preserved their productive capacity. The parents felt proud of how their children interacted in the contexts in which they lived.

When the children were adults, responsibility for caring for the rare disease patient was no longer an exclusive commitment from the parents. A mother, F2, mentioned that as her child grew it became progressively more difficult to control his daily care and treatment. She recognized it was necessary to preserve her child's autonomy as an adolescent/adult, student, worker, citizen and also as a person who is aware of his condition: [...] I think that before I had control of the situation because I knew that when he stood up he would do everything, not so today. Nowadays, I can no longer force him - he is a grown man [...] (F2).

F4 said that preserving family life is developing the sense of protecting a child with a rare disease. Protecting with the purpose of being more aware, but not labeling him as a sick person: We have never hidden the fact that he has a heal th problem. We do not say he is sick, we say he has a health problem. Of course, we have always protected him, even if unwillingly. Even if we don't want to [admit], we do feel that we have protected him a little bit more (F4).

F4 also said that a rare disease's characteristics of severity and chronicity lead to existential reflections on death and dying, both by the affected person and for the other family members. However, she admits that in family life, avoiding talking about the process of life and death is an established care routine. It is a veiled issue: [...] we also do not say these words to him [dying/death]; what we do say is: 'come on, let's do it, you will overcome' (F4).

\section{DISCUSSION}

The priority needs indicated by the families of rare disease patients are similar to those manifested by families suffering from diseases that occur more frequently in the population. However, a detailed analysis shows that they assume a different characteristic that is determined not by the morbid condition but by the resolution of the professional practices and the way in which the services are organized. These families are usually treated in unequal manner by the healthcare services, but not due to prejudice. Their rights to have access to quality 
healthcare services, equality, resolution and integrity of the actions are not always respected either because the services do not have the technological resources to care for a rare condition or because the professionals themselves are not prepared.

All the families who participated in the study mentioned access as a priority. In Brazil, equal access to healthcare services has been guaranteed by the federal Constitution since $1988 .{ }^{1}$ However, if access means receiving quality care as required, offered in a proper and appropriate place and considering the geographical dispersion ${ }^{9}$ of the families under investigation, the inequality in comparison with other chronic diseases is clear. The other chronic diseases that are included in the public health policies and programs, such as the Family Health Strategy are, for example, hypertension, diabetes mellitus, tuberculosis and hanseniasis, for which assistance is guaranteed at all levels.

The need to know what was going on with their children's health was also significant to the interviewed families. The families used the Internet as the source of information both at the time of diagnosis and to add to the information provided by the doctor. In rare diseases, this behavior seems to be common due to the difficulty of finding qualified healthcare services and affected people in the same population. The links this public visits the most are the virtual support groups, blogs and information websites. ${ }^{10-11}$ A study ${ }^{12}$ pointed to the importance of social groups who experience a similar situation, such as healthcare teams and associations. Sharing experiences, both virtual or in person, is equal to receiving support to go on. A healthcare team that can support the family and understand the human relations and reactions, without neglecting the medical technique, is particularly important. ${ }^{12}$ It is worth highlighting that the initial stage of the family's relationship with a rare disease is permeated by fear and frustration due to lack of knowledge about the disease. Therefore, contact with other families who experience similar difficulties is a source of support and solidarity.

Other needs mentioned by all the families involve the family and social structures, which are divided into financial support, support to care for the child and spiritual support. Social psychology studies mention that several types of social support are considered essential for the well-being and maintenance of health. ${ }^{13}$ The results of this study resonate in a study performed with families of cystic fibrosis patients that pointed to the importance of social support through patient associations, which are significant instances to respond to the family's needs. ${ }^{14}$
The issue of the rarity of these diseases has an important dimension in the life of the families and patients: their life in society. The need for the rare disease patient's and family's acceptance and social insertion is a significant issue observed in this study. The nursing team needs to assess risk behaviors that could endanger social integration, such as psychological imbalances. It is important to highlight the need to evaluate and monitor rare disease patients and their families with regard to manifestations such as feelings of isolation, selfdepreciation, marginalization and insecurity, as well as symptoms of anxiety, affective lability and depression, which are mentioned in other studies that analyze the relationship between rare diseases and these symptoms. ${ }^{15}$

The families in the study indicated that in spite of the problems experienced with the rare disease, they have been able to create a favorable family environment for the patient's. Preserving their personal lives was a need and an important strategy to maintain family identity. Authors have reinforced this idea from a study with families of cystic fibrosis patients resident in the State of Paraná, which showed that their children became able in school, college and/or work activities and led active social and affective lives. ${ }^{12}$

Similarly, it was observed that preserving the children's autonomy was essential for the families with adolescent/adult children in this study. A study developed with chronic disease adolescent patient showed results similar to this study's. ${ }^{16}$ Even though these adolescents tried to lead life like their counterparts, it was necessary for them to be aware of their disease, special care and responsibilities. Another factor indicated by the interviewed families was interacting with the possibility of death. This causes fear, insecurity and lack of ability to talk about the subject with the family member. Authors state that nursing can be the difference in the process of discussing and accepting the new reality, reducing frustrations and fears. ${ }^{17}$

\section{CONCLUSION}

Although this study has considerable limitations that result from its qualitative nature and reduced number of participants, the set of needs indicated as priority by the families of rare disease patients is a basis to reflect on important issues related to these patients' health. The organization of healthcare services and their professional practices are among the issues raised. 
Rare diseases represent a great challenge because they require strategies that can improve access to prevention and diagnostic services and to patient treatment. Nevertheless, a rare disease is a condition that in some way places the patients and their families on the margins of the healthcare system, which is usually organized to cater for more frequent diseases in the population. Families are therefore faced with a condition of greater vulnerability not only because one of its members has a pathology but especially because the diagnosis is not always forthcoming and they rarely find services prepared to care for them. At the same time, these families need to adapt to new functions, reorganize their lives to assume the care that the disease demands.

However, it is necessary to be aware that working with rare disease patients and their families does not mean working with a minority but with significant repercussions of growing relevance not only for the families but also for the professionals, managers and social and healthcare institutions. Care for this part of the population must include services and professionals capable of responding to their needs and acting in the primary, secondary and tertiary level. The fact that in Brazil the reference services are few and usually located in large cities, making access to the families that live in smaller municipalities difficult, must also be taken into consideration. Moreover, the resources offered by the municipalities for transportation and education do not always fully meet the families' needs. The need for nursing to be supported by other areas, such as law, to offer support to the families in a decisive manner becomes clear.

\section{REFERENCES}

1. Ministério da Saúde (BR). Portaria n 199 de 30 de janeiro de 2014: Institui a Política Nacional de Atenção Integral às Pessoas com Doenças Raras, aprova as Diretrizes para Atenção Integral às Pessoas com Doenças Raras no âmbito do Sistema Único de Saúde (SUS) e institui incentivos financeiros de custeio. Brasília (DF): MS; 2014.

2. Dominguez B. Pessoas afetadas com doenças complexas e pouco conhecidas se mobilizam para viabilizar políticas públicas e combater preconceitos. Radis [internet]. 2015 Feb [cited 2016 Apr 21]; 149:12-7. Available from: http://www6.ensp.fiocruz.br/radis/ sites/default/files/radis_149_site.pdf

3. Aith F, Bujdoso Y, Nascimento PR, Dallari SG. Os princípios da universalidade e integralidade do SUS sob a perspectiva da política de doenças raras e da incorporação tecnológica. Rev Direito Sanitário [internet]. 2014 [cited 2016 Apr 21]; 15(1):10-39.
Available from: http:/ / www.revistas.usp.br/rdisan/ article/view/82804

4. Anderson M, Elliott EJ, Zurynskil YA. Australian families living with rare disease: experiences of diagnosis, health services use and needs for psychosocial support. Orphanet J Rare Dis [internet]. 2013 [cited 2016 Apr 21]; 8:22. Available from: http:/ / www.ncbi.nlm.nih.gov/pubmed/23398775.

5. Guillevina L. The national plan for orphan rare diseases: nearly 10 years on. Rev Neurol 2013; 169 (1 Suppl 1):S9-11.

6. Luboya E, Tshilonda JCB, Ekila MB, Aloni MN. Psychosocial impact of sickle cell disease in the parents of children living in Kinshasa, Democratic Republic of Congo: a qualitative study. Pan Afr Med J. 2014; 19:5.

7. Bronfenbrenner U. Making human beings human: bioecological perspectives on human development. California (US): Sage Publication; 2005.

8. Elo S, Kääriäinen M, Kanste O, Pölkki T, Utriainen K, Kyngäs H. Qualitative content analysis: a focus on trustworthiness. [internet]. Sage Open. 2014 [cited 2016 Apr 21]; 1-10. Available from: http:/ / sgo. sagepub.com/content/4/1/2158244014522633.

9. Luz GS, Silva MRS, DeMontigny F. Doenças raras: itinerário diagnóstico e terapêutico das famílias de pessoas afetadas. Acta Paul Enferm [Internet]. 2015 Dec [cited 2016 Apr 22]; 28(5):395-400. Available from: http://www.scielo.br/pdf/ape/v28n5/1982-0194ape-28-05-0395.pdf

10. Frossard VC, Dias MCM. O impacto da internet na interação entre pacientes: novos cenários em saúde. Interface Comunicação, Saúde Educação. [Internet]. 2016 [cited 2016 Apr 22]; 20(57):349-61. Available from: http://www.scielo.br/pdf/icse/2016nahead/18075762-icse-1807-576220141334.pdf

11. Pimentel EC, Luz GS, Pelloso SM, Carvalho MDB. Using the internet to exchange information and experience on cystic fibrosis. Investigación Educ Enferm [internet]. 2013 [cited 2016 Apr 22];31(3):457-63. Available from: http:/ / aprendeenlinea.udea.edu.co/ revistas/index.php/iee/article/view/17506/15234

12. Tavares KO, Carvalho MDB, Pelloso SM. Difficulties experienced by the mothers of people with cystic fibrosis. Texto Contexto Enferm [internet]. 2014 AbrJun [cited 2016 Apr 22]; 23(2): 294-300. Available from: http://www.scielo.br/scielo.php?pid=S010407072014000200294\&script=sci_arttext\&tlng=pt

13. Gauducheau N. Internet et le soutien social. In: Thoer C, Levy JJ. Internet et Santé: acteurs, usage et appropriations. Quebec (CA) : Presses de l'Université du Quebec; 2012. p. 506.

14. Luz GS, Carvalho MDB, Silva MRS. The meaning of a cystic fibrosis support organization from the family perspective. Texto Contexto Enferm [internet]. 2011 [cited 2016 Apr 22]; 20(1):127-34. Available from: http:/ / www.scielo.br/scielo.php? script=sci arttext\&pid=S0104-07072011000100015 
15. Afonso SBC, Gomes R, Mitre RMA. Narrativas da experiência de pais de crianças com fibrose cística. Interface Comunic, Saúde Educ [internet]. 2015 [cited 2016 Apr 22]; 19(55):1077-88.Available from: http:/ / www.scielo.br/scielo.php?pid=S141432832015000401077\&script=sci_abstract\&tlng=pt

16. Barbosa TA, Reis KMN , Lomba GO, Alves GV, Braga PP. Rede de apoio e apoio social às crianças com necessidades especiais de saúde. Rev Rene [internet]. 2016 Jan-Feb [cited 2016 Apr 22]; 17(1):60-6. Available from: http://www.revistarene.ufc.br/revista/index. $\mathrm{php} /$ revista/article/viewFile/2195/pdf

17. Barreto TSM, Sakamoto VTM, Magagnin JS, Coelho DF, Waterkemper R, Canabarro ST. Experience of parents of children with congenital heart disease: feelings and obstacles. Rev Rene [internet]. 2016 JanFeb [cited 2016 Apr 22]; 17(1):128-36. Available from: http://www.periodicos.ufc.br/index.php/rene/ article/view/2614 